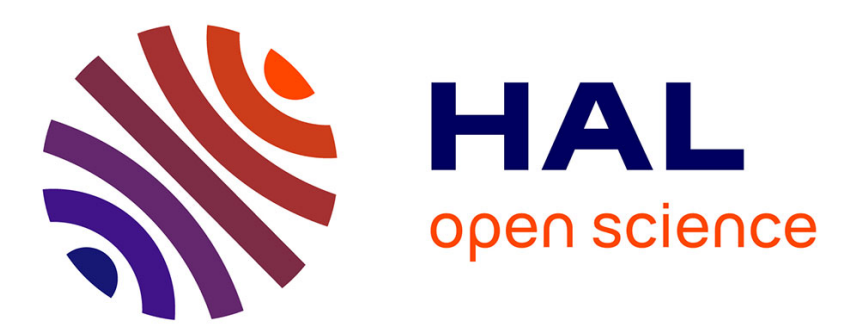

\title{
Simulated impacts of climate change and land-clearing on runoff from a small Sahelian catchment
}

L. Seguis, B. Cappelaere, G. Milesi, C. Peugeot, Sylvain Massuel, Guillaume Favreau

\section{- To cite this version:}

L. Seguis, B. Cappelaere, G. Milesi, C. Peugeot, Sylvain Massuel, et al.. Simulated impacts of climate change and land-clearing on runoff from a small Sahelian catchment. Hydrological Processes, 2004, 18 (17), pp.3401-3413. 10.1002/hyp.1503 . ird-00187211

\section{HAL Id: ird-00187211 \\ https://hal.ird.fr/ird-00187211}

Submitted on 13 Nov 2007

HAL is a multi-disciplinary open access archive for the deposit and dissemination of scientific research documents, whether they are published or not. The documents may come from teaching and research institutions in France or abroad, or from public or private research centers.
L'archive ouverte pluridisciplinaire $\mathbf{H A L}$, est destinée au dépôt et à la diffusion de documents scientifiques de niveau recherche, publiés ou non, émanant des établissements d'enseignement et de recherche français ou étrangers, des laboratoires publics ou privés. 
Simulated impacts of climate change and land-clearing on runoff from a small Sahelian catchment

L. Séguis, B. Cappelaere, G. Milési, C. Peugeot, S. Massuel, G. Favreau

This is a preprint published in :

\section{Hydrological Processes}

available online at: http://www3.interscience.wiley.com/cgi-bin/jhome/4125

Volume 18, Pages 3401-3413, October 2004

doi:10.1002/hyp.1503 
Title:

\section{Simulated impacts of climate change and land-clearing on runoff from a small Sahelian catchment}

Short title:

Climatic and anthropic effects on Sahelian runoff

Authors:

L. Séguis, B. Cappelaere*, G. Milési, C. Peugeot, S. Massuel, G. Favreau

U.M.R. Hydrosciences, Institut de Recherche pour le Développement (I.R.D.), Montpellier, France

*Correspondence to :

B. Cappelaere,

IRD, UMR Hydrosciences, B.P. 64501, 34394 Montpellier Cedex 5, France.

Ph.: +33 (0) $4679017 \quad$ Fax: +33 (0) 467144774

E-mail : bernard.cappelaere@mpl.ird.fr 


\begin{abstract}
In the Sahel, there are few long-term data series available to estimate the climatic and anthropic impacts on runoff in small catchments. Since 1950, land clearing has enhanced runoff. The question is whether and by how much this anthropic effect offsets the current drought. To answer this question, a physically-based distributed hydrological model was used to simulate runoff in a small Sahelian catchment in Niger, from the 1950-1998 rain series. The simulation was carried out for 3 soil surface states of the catchment (1950, 1975 and 1992). The catchment is characterized by an increase in cultivated land, with associated fallow, from 6 $\%$ in 1950 to $56 \%$ in 1992, together with an increase in the extent of eroded land (from 7 to 16 $\%$, at the expense of the savanna. Effects of climate and land use are first analysed separately: irrespective of the land cover state, the simulated mean annual runoff decreases by about $40 \%$ from the wet period (1950-1969) to the dry period (1970-1998); calculated on the 1950-1998 rainfall series, the changes that occurred in land cover between 1950 and 1992 multiplies the mean annual runoff by a factor close to 3 . The analysis of a joint climatic and anthropic change shows that the transition from a wet period under a "natural" land cover (1950) to a dry period under a cultivated land cover (1992) results in an increase in runoff of the order of 30 to $70 \%$. At the scale of a small Sahelian catchment, the anthropic impact on runoff is probably more important than that of drought. This figure for relative increase in runoff contributions to ponds, preferential sites of seepage to groundwater, is less than that currently estimated for aquifer recharge, which has been causing a significant continuous water table rise over the same period.
\end{abstract}

\title{
Key words
}

Sahel; distributed modelling; climatic change; Hortonian runoff; land cover change 


\section{INTRODUCTION}

Current studies on climate variability emphasize the consequences of change for the environment. In tropical regions, drainage is particularly sensitive to any climatic changes. In sub-Saharan Africa, the occurrence of drought from the seventies on has resulted in a decline in the flow rate of the largest rivers. For a $20 \%$ decrease in rainfall in comparison with the previous period (Nicholson et al., 2000), the average annual discharge of the largest rivers in the region (Niger, Senegal) fell by $40 \%$ (Paturel et al., 1997). Less dramatic rain shortage in recent years did not cause runoff to approach former averages (Bricquet et al., 1997; Mahé et al., 2000). Although the above-mentioned rivers have parts of their course in semi-arid, Sahelian countries, their contributing areas are located further south under much wetter, Guinean climate. Declining river flows have been reported for many humid watersheds in Western and Central Africa (Servat et al., 1997).

Due to distinctive features of the Sahelian environment (sandy soils, aeolian sand deposits, gentle slope, high evaporation and small annual number of rainfall events, which induce drainage network degradation and widespread endoreism), runoff generally accumulates to ponds (Desconnets et al., 1997) or infiltrates along the drainage network: there are few significant Sahelian rivers and, consequently, very little long-term record of Sahelian runoff. In a study of the specifically Sahelian tributaries of the Niger River in Burkina Faso, Mahé et al. (2003) report an increase in discharge over the last 40 years, contrasting with the observed rainfall reduction. In the major part of the Sahel, runoff occurs only at a local scale within small catchments, none of which has been monitored continuously over as long a period. Sites where observations were made both in the wet 1950's and during the later drought years are extremely rare. From aerial photograph comparison and village inquiries in the area of the Hapex-Sahel experiment (Goutorbe et al., 1994) in south-western Niger, Favreau (2000) gathered qualitative evidence of increased runoff over the last half-century that includes significantly more abundant runoff-fed pool water (larger pond number and volumes), and increased gullying (see also Favreau et al., 2002b). In two catchments in Burkina Faso under Sudanese climate (700-950 mm of annual rainfall), Albergel (1987), using a hydrological model, 
showed that the present decrease in rainfall seems to be widely compensated for by runoff caused by environmental changes. These environmental changes consist mainly of the extension of cultivated land required by a dramatic population increase: in the Sahel, a steady growth rate of $3 \%$ a year causes the population to double every 20 years since the Second World War (Le Houérou, 1993). Under the influence of this demographic pressure, natural areas have been cleared and cultivated; and since this land has less vegetation, it is then more prone to erosion by wind and water (Bajracharya and Lal, 1999). Subsequently, when all the arable land has been exploited, a decrease in the duration of fallow is observed (Loireau, 1998). All these factors contribute to degradation of the environment resulting in crusting of the soil surface (Valentin, 1994) that enhances surface runoff. Unlike more humid watersheds where the climatic factor appears to dominate the hydrologic response, Sahelian runoff seems to be more dependent on land surface conditions whose effects mask the rainfall decline. This contrast may be explained by differences in hydrological processes between the two regions, i.e. mainly infiltration and subsurface/"contributing-area" processes in wetter areas, versus surface runoff and Hortonian processes in the Sahelian zone. Pouyaud (1987) suggested that groundwater drying-up is responsible for the lasting discharge decrease in humid catchments. In Sahelian areas, the water table is generally too deep below the land surface to affect surface water.

In fact, in the Hapex-Sahel area, the Continental Terminal groundwater has been undergoing a continuous, regional rise for over 40 years, as described by Leduc et al. (1997, 2001). The authors attribute this to the anthropogenic increase in surface runoff that accumulates into a large number of endoreic ponds where it can infiltrate to the water table. They rule out (Favreau et al., 2002b) the hypothesis of diffuse groundwater recharge under millet fields (Gaze et al., 1998; Bromley et al., 2002) as a major mechanism. The aim of the present paper is to produce estimates for possible fluctuations of runoff to a typical pond in the area since the 1950's, and confront them with the observed groundwater rise. For lack of surface water data before 1992, a hydrological model (Cappelaere et al., 2003b; Peugeot et al., 2003) is used to explore by simulation the changes in runoff to the Wankama pilot pond in 
relation to climatic and environmental changes over the last 50 years. In the first part of the paper, catchment characteristics and modelling methodology based on available data are presented. Next, results of simulations are used to assess the respective influences of climate and environment modifications on surface water resources. Finally, the simulated changes in pond recharge are compared with the groundwater information for the period.

\section{STUDY SITE AND HYDROLOGICAL FUNCTIONING}

The region to the east of Niamey is occupied by the Miocene sandy-loamy sediments of the Continental Terminal covered locally with dunes from the late Quaternary. The landscape appears as an armoured laterite plateau cut by wide fossil valleys called locally Koris. The hydrographic network inherited from wetter conditions during the Quaternary no longer functions. During the rainy season (June - September), the lowest parts of valleys are occupied by a series of ponds that collect the runoff from the hillsides in a mosaic of disconnected endoreic catchments of only up to a few square-kilometers. Typically in this region, the depth to the water table varies from at least 15-30 m (below ponds) to well over $60 \mathrm{~m}$; therefore surfaceand ground- waters show only a one-way connection, that is aquifer recharge. Runoff occurs as Hortonian overland flow. During the most intense rain events, ponds may overflow from one to the other. Hydrographic degradation characterized by interruption of concentrated drainage is the major feature of the hydrological functioning. This degradation is encountered in valleys blocked with sandy bolts but also on hill slopes between the plateau and the valley bottom. The plateau escarpment is relatively steep and thus favours runoff. The sheet flow is rapidly concentrated in 1-2 m deep gullies with sandy beds. However due to the decrease in the steepness of the slope of the hillsides, the gullies rapidly decrease in depth and split into multiple arms forming spreading zones where the majority of runoff is absorbed. After crossing these zones, the remainder of the flow is again concentrated in gullies thanks to flow contributions from the downhill part of the catchment. Finally, the flow ends in ponds located in the beds of former streams.

The Wankama catchment presents all the features of the above description and is 
representative of the area. It is located between a plateau at an altitude of $265 \mathrm{~m}$ and the valley of the so-called Dantiandou Kori at an altitude of $200 \mathrm{~m}$. The surface area is $1.9 \mathrm{~km}^{2}$ and the mean slope is $2 \%$. In the middle of the hillside, the gully presently forms a spreading zone about $225 \mathrm{~m}$ in width and $400 \mathrm{~m}$ in length. Below the spreading zone, the gully flows into a pond in the bed of the Kori. Pond water levels and rainfall have been recorded since 1992 (Peugeot et al., 2003). Aerial photography was carried out in 1950, 1975 and 1992 for topographic purposes, providing us with ortho-photos of the catchment at these dates. Although a break in the gully is distinguishable in the photos taken in 1950 and 1975, it is difficult to quantify the extension of the spreading zone. Further details on the study site and on the area's hydrology can be found in Peugeot et al. (2003).

\section{LAND USE CHANGES DURING THE LAST FIFTY YEARS}

Casenave and Valentin (1992) developed the concept of "soil surface features" to characterize the infiltration/runoff properties of the various types of soil surfaces encountered in the Sahel region. As explained below, Casenave and Valentin's classification (1992) associates to each soil surface feature class an estimate of the infiltration rate derived from rainfall simulation experiments. Based on this concept, d'Herbès and Valentin (1997) produced a soil surface feature map for the Niamey area including the Wankama catchment for 1992, by classifying SPOT multi-spectral images at a resolution of $20 \mathrm{~m}$ together with transects obtained from field surveys. Similarly, we interpreted the photos taken in 1950 and 1975 . The resulting three instantaneous maps of the catchment taken at an interval of about 20 years are presented in Figure 1 (surface types have been simplified to four classes in the figure for legibility). Area distributions are given in Table 1. It may be noted that a radical change in the landscape has taken place over the last 50 years. In 1950, the catchment presented a natural land cover of shrub savanna, with crops only occupying $6 \%$ of the catchment near the pond. In 1975 , the crop-fallow system represented $17 \%$ of the catchment area, with fields spread over the lower part of the catchment. Land clearing and cropping resulted in a degradation of the environment: with regard to the 1950 map, degraded surfaces with hard crusting and sparse vegetation had expanded from 7 to $21 \%$. By 1992, the crop-fallow system had become predominant in the 
catchment (56\%). Although it is possible to quantify the major features of changes in the catchment by interpreting the photos, some uncertainties remain: for example it is difficult to imagine a decrease in degraded surface areas from $21 \%$ in 1975 to $17 \%$ in 1992 . No restoration or conservation practices likely to slow down or even inverse degradation processes were undertaken during this period. This variation may be attributable to an overestimation of degraded areas in 1975: certain fields of intense brightness may have been allocated to this class by mistake. The landscape's drastic change should be considered in the context of the demographic explosion in the region. Loireau (1998), on a nearby site, determined that the population had increased by a factor of 18 between 1950 and 1995 .

Casenave and Valentin (1992) built their classification of the various soil surface conditions encountered in the Sahel region on the basis of rainfall simulation data from 87 plots, using as criteria the key factors in term of hydrological behaviour: surface crust type, faunal activities (e.g. termites), woody and herbaceous vegetation cover, surface roughness. Soil surface feature units can be mapped from field survey (Valentin, 1986) or from remote sensing image analysis (Lamachère and Puech, 1996). The infiltration rate estimates derived by Casenave and Valentin (1992) from the rainfall simulation experiments are consistent with direct measurements of saturated hydraulic conductivity, $K_{s}$ (Valentin, 1991; Peugeot et al., 1997; Vandervaere et al., 1997). Based on Casenave and Valentin's table (infiltration -versus- surface feature class), a 20-m resolution $K_{s}$ map can be obtained for each of the three epochs considered here, by reclassifying the respective land surface maps according to Table 1 . The same can be done for the Manning roughness parameter $(n)$, using estimates produced by Desconnets et al. (1996) for the surface feature classes encountered in the Niamey area (Table 1). More information on the hydraulic parameter values used for the Wankama catchment model can be found in Peugeot et al. (2003).

The mean saturated hydraulic conductivity of the catchment is equal to 57,45 and $37 \times 10^{-7}$ m. $\mathrm{s}^{-1}$ for the respective land surfaces in 1950, 1975 and 1992. At the same dates, the mean Manning roughness parameter is equal to $0.176,0.138$ and $0.122 \mathrm{~m}^{-1 / 3} \mathrm{~s}$, respectively. At the 
scale of the whole catchment, under the same rainfall conditions, runoff should increase from the 1950 state to the 1992 state, because infiltration $\left(K_{s}\right)$ decreases and the routing time related to the roughness coefficient $(n)$ decreases. Due to low resolution with respect to gully width, the drainage network is not taken in account in the statistics given in Table 1. It is assigned values of $K_{s}=1250 \times 10^{-7} \mathrm{~m}^{-1}{ }^{-1}\left(450 \mathrm{~mm} \mathrm{~h}^{-1}\right)$ and $n=0.03 \mathrm{~m}^{-1 / 3} \mathrm{~s}$, which are representative of a small, clean sandy bed.

\section{HYDROLOGIC MODEL}

Sahelian rainstorms are mainly convective systems, i.e. of high intensity and short duration (d'Amato and Lebel, 1998; Lebel et al., 1997). Runoff is thus Hortonian: overland flow occurs when the rainfall rate is greater than the $K_{s}$ of the surface layer. All simulations have been performed with the physically-based, two-dimensional, distributed model r.water.fea (Vieux and Gaur, 1994), after it was upgraded and implemented by Cappelaere et al. (2003b) and Peugeot et al. (2003) for the Wankama catchment. The model runs in the GRASS GIS environment (USACE, 1993) over a raster grid. Maps of the watershed geometry (catchment and channel network layout, rasterized drainage directions) produced from a DEM (Digital Elevation Model) by GRASS's r.watershed function, define the discrete model structure. The production and routing functions are fully coupled, allowing simulation of runoff from and run-on to each cell of a raster grid within the catchment. The kinematic-wave, Manning and Green-Ampt equations are solved concurrently using finite-elements in space and an explicit finite-difference scheme in time (Vieux, 2001; Séguis et al., 2002). Model parameters (saturated conductivity, capillary pressure head at the wetting front, Manning coefficient) as well as land slope are handled as GRASS raster maps. Although r.water.fea can be run with distributed rainfall maps, only spatially uniform rainfall is considered here. The model is operated on an event basis: an initial soil moisture map is input to the model, which, for the purposes of the present simulation, is considered to be uniform over the whole catchment, as explained below. The initial soil moisture is deduced from an Antecedent Precipitation Index calibrated on observed soil values 
monitored during two years (Peugeot et al., 2003). A uniform value of $20 \mathrm{~cm}$ is taken for the capillary pressure head at the wetting front $H_{f}$.

The Wankama model was calibrated and validated by Cappelaere et al. (2003b) on rainfallrunoff events that occurred from 1992 to 2000 . The fitting parameters are dimensionless scaling factors, of which there are three, $\mathrm{K}, \mathrm{C}$ and $\mathrm{M}$. These scaling factors are applied to the a priori values of the model's hydraulic parameters: $\mathrm{K}$ is the uniform multiplier applied to the 1992 raster map of spatially distributed values of hillslope hydraulic conductivity, C is the one applied to channel hydraulic conductivity and $M$ is applied to the 1992 map of Manning's roughness coefficient. The relative spatial patterns within each map are thus preserved. Optimal values were found to be $\mathrm{K}=0.75, \mathrm{C}=1$ and $\mathrm{M}=1.25$. When expressed as an equivalent to Nash-Sutcliffe efficiency coefficient, performance in calibration, cross-validation, and split-sample test is always largely above $90 \%$, meaning that the model is able to reproduce the observed catchment behaviour for the $1992-2000$ period very correctly. It can be noted that optimal multiplicative factors are moderate: fitted hydraulic characteristics differ by only $25 \%$ from the prescribed values in Table 1. The uncalibrated model also performs quite acceptably well, with an equivalent Nash-Sutcliffe also above $90 \%$. There does not seem to be any parameter drift over the 1992-2000 period. Parameter and predictive uncertainty was analysed by Cappelaere et al. (2003b). Cappelaere et al. (2003a) showed that the resulting uncertainty is quite small for seasonal pond recharge prediction: it is in the order of $10 \%$ for annual predictions and $3 \%$ for interannual mean over the 1992-2000 period.

It is assumed that, thanks to this parameterisation scheme and limited-calibration approach (a small number of degrees of freedom favours capture of actual catchment properties, rather than noise in the data), model calibration and uncertainty analysis are not tied to the present land use situation, i.e., that the hydraulic scaling factors can be transposed to the 1950 and the 1975 land maps. Taking this stand is reasonable given the physically-based, fully spatiallydistributed nature of the model, with an explicit representation of the detailed structure of this small catchment, as opposed to more conceptual, lumped models which would require 
recalibration. Good performance of the uncalibrated model and proximity of calibrated parameters to their prior values lend credit to the quality of model construction, and backs model transposition to different land cover states, consisting in new spatial distributions of the same land units.

\section{SIMULATION PROTOCOL}

For each of the 3 soil surface states of the Wankama catchment, runoff is calculated with the r.water.fea model for the 1950-1998 rainfall series. Rainfall recording only began in 1992 at Wankama. We therefore used data from the closest long-duration station, at Niamey Airport (60 $\mathrm{km}$ to the west). Over the long term, the Niamey airport series is statistically representative of rainfall in Wankama (Lebel et al., 1997). Mean annual rainfall decreased from $646 \mathrm{~mm}$ before 1969 to $493 \mathrm{~mm}$ since then, i.e. a decline of about 24\% (Figure 2). This marked decrease and the date of the break are comparable to those observed at other Sahelian sites (d'Amato and Lebel, 1998; Hulme, 1992). We distinguish a wet period (1950-1969) and a dry period (19701998).

All daily rainfall depths are available but there are gaps in the records of instantaneous rainfall intensities. To fill these gaps and obtain a complete series, we proceeded in the following way: (i) based on their total precipitation depth, observed hyetographs were pooled into 5-mm wide depth classes; (ii) for a rainfall day with no available hyetograph, a hyetograph was randomly selected from the class with the same rainfall depth.

A stationarity study of the Niamey rainstorm characteristics over 1956-1998 showed significant changes in the structure of the hyetographs especially for the events between 20 and $35 \mathrm{~mm}$, before and after 1969 (Lubès-Niel et al., 2001). The missing hyetographs for a given period were randomly selected from among the available hyetographs in the same period and rain-depth class. Before 1956, the precision and reliability of the rain gauge was insufficient to calculate intensity at a 5-minute time step. Consequently, from 1950 until 1955, the entire 
hyetograph series was generated. After 1990 there are no more gaps thanks to the installation of a pluviograph with an electronic clock and magnetic storage.

The reconstituted pluviographic series from 1950 until 1998 contains 2909 events, of which $38 \%$ were generated. The lowest rainfall depths (less than $10 \mathrm{~mm}$ ) represent the majority $(71 \%)$ of the generated events. Using five generated series, we verified that the average coefficient of variation of annual rainfall is low $(0.8 \%)$. In a preliminary simulation, we also verified that annual runoff is relatively insensitive to the stochastic character of the hyetogram series. The whole study is thus made with one series selected from the five.

In addition to the optimal (K, C, M) triplet, we retained 23 other triplets that can correctly reproduce $75 \%$ of rainfall-runoff events of the calibration period (1992-1998) (Cappelaere et al., 2003b). Due to the difficulty in interpreting the extent of the spreading zone using the photos taken in 1950 and 1975, simulations were performed either using the dimensions of the existing spreading zone ( $400 \mathrm{~m}$-long by $225 \mathrm{~m}$-wide) or neglecting it, i.e. with a width equal to that of the rest of the channel $(2 \mathrm{~m})$. A total of 144 simulations were performed (24 parameter sets by 3 surface feature maps by 2 spreading zone widths), over the entire 1950-1998 rain series.

\section{RESULTS}

In this section we will first analyse the influence on annual runoff of environmental changes (land use and spreading zone width). Next the influence of climatic changes, i.e., wet period (1950-1969) versus dry period (1970-1998), will be discussed. Finally the consequences for runoff of coupled modifications will be evaluated.

\section{Environmental change}

Figure 3 shows simulated annual runoff versus annual rainfall for each of the three surface feature maps $(1950,1975$ and 1992) through the 49 rain years, successively for the two 
spreading zone widths. To runoff obtained with the optimal (K, C, M) triplet, we added the interval of variation of runoff calculated with the 23 other $(K, C, M)$ sets.

As we anticipated at the end of the land use section, irrespective of annual rainfall, the runoff calculated with the optimal parameter set increases when changing the landscape from the 1950 state to the 1992 state. By analysing the intervals of runoff variation, it will be noted that whatever the $(\mathrm{K}, \mathrm{C}, \mathrm{M})$ triplet, runoff produced with the 1950 surface feature map is systematically lower than that produced with the 1992 surface feature map. Runoff intervals overlap only between the intermediate 1975 surface feature map and the two extremes (in 1950 or 1992). On average over the 1950-1998 rain series, the annual runoff almost tripled between the catchment with natural vegetation (1950) and the cropped catchment (1992) (see Table 2; values presented in this table and in the rest of the paper are those obtained for the optimal calibrated parameter set). Annual runoff nearly doubled between the 1950 and the 1975 soil surface states. Even though the field-fallow rate in the 1975 catchment remains small (17\%) and natural vegetation remains prominent (60\%), this doubling is probably due to the increase in eroded surfaces (from 7 to $21 \%$ ) mostly in the lower part of the catchment.

Increasing the spreading zone width alone lowers annual runoff by only 18 to $24 \%$ : runoff variations connected to a modification in the spreading zone appear to be of second order in comparison with those due to changes in land use.

\section{Climatic change}

For every land surface state, we calculated and compared the average runoff over the wet (1950-1969) and dry (1970-1998) periods. The decrease in rainfall (23\%) between the two periods is amplified by the watershed: the runoff decrease ranges from 37 to $40 \%$ (Table 3), i.e., it is nearly independent of land use and of spreading zone width. Figure 4 shows the contributions of each of the nine rainfall depth classes to the total deficits (wet to dry period) in rain (observed) and in runoff (simulated, with 1992 land use and a 225-m spreading zone 
width). Rainstorms with less than $20 \mathrm{~mm}$ depth represent a third of the rainfall deficit but only $3 \%$ of the runoff deficit. Runoff deficit is essentially due to heavy rainstorms: rainstorms of more than $30 \mathrm{~mm}$ (55\% of the rainfall deficit) generate $84 \%$ of the runoff deficit.

\section{Combined climatic and environmental modifications}

Climatic and environmental changes having been dealt with separately, we now present the impact on runoff of combined changes. Figure 5 shows plausible scenarios for the fifty-year period: there is not just one scenario because the spreading zone width is uncertain for 1950 and 1975. It can be seen that simulated runoff is significantly larger in 1992 than in any of the previous situations. Depending on the spreading zone hypothesized for 1950, relative increase in runoff from 1950 to 1992 is 31 or $72 \%$. Comparison of the two successive phases of landscape and climatic changes (1950-1975 and 1975-1992) shows that, no matter which spreading zone hypothesis, runoff increase is higher in the second phase where only environment change occurs.

\section{DISCUSSION AND CONCLUSION}

The proposed objective was to explore by simulation the respective impacts on runoff of the climatic and environmental changes that have occurred over the last 50 years in a small Sahelian catchment. The interpretation of available photos (taken in 1950, 1975 and 1992) and the transcription of the soil surface features into hydraulic parameters by Casenave and Valentin's method (1992) enabled hydrological characterization to be carried out.

As expected in this area, past land use changes alone were found to greatly increase runoff. Lørup et al. (1998) pointed out that significant rural population densification does not systematically entail increased surface runoff everywhere in semi-arid Africa: working in Zimbabwe on six larger catchments with $620-800 \mathrm{~mm}$ annual rainfall, they found a tendency for a slight decrease in annual runoff (noise due to climate variability having been removed). In this case, land use modifications essentially consisted in crop substitution (from finger millet to more 
water demanding maize and sunflower, with moderate farmed surface expansion) and associated changes in cultivation practices that improve infiltration in comparison with former cropped, grazed, or natural surfaces. Also, runoff generation mechanisms may be different from the Sahel, soil moisture status seeming more important than vegetation cover for runoff production. In our study area, where runoff occurs only at a much smaller scale and is mainly controlled by land surface conditions, replacement of natural savanna by extensive, low-density, hand-hoed millet cultivation enhances overland runoff production (Casenave and Valentin, 1992) through reduced surface permeability and roughness. This also appears to be the case for the larger Sahelian catchments studied by Mahé et al. (2003) in Burkina Faso, where discharges were found to increase, despite reduced rainfall.

Our hydrological simulations evidence the dominant effect of past environment changes over climate change on runoff in the Wankama catchment, in agreement with available signs of runoff increase in the area (Favreau, 2000; Favreau et al., 2002b; Leduc et al., 1997, 2001). If only environmental changes are considered, i.e., an increase in the crop-fallow system (from 6 to $56 \%$ ) and in eroded zones (from $7 \%$ to $17 \%$ ) at the expense of natural vegetation (from $85 \%$ down to $24 \%$ ) as incurred over the last half century, then runoff is found to grow by 2.6 to 2.8 times depending on the drainage network considered, whereas the concomitant climatic deterioration (23\% rainfall decrease from the wet 1950-1969 period to the dry 1970-1998 period) would normally result in a runoff decrease of only $40 \%$. The combined modifications in climate and environment generate runoff 1.3 to 1.7 times as high at present than in the 1950 situation: in terms of runoff, environmental modifications due to clearing and cropping overcompensate for the drought that has occurred since 1970. The largest runoff increase scenario (from $21 \mathrm{~mm} / \mathrm{year}$ in 1950 to $36 \mathrm{~mm} / \mathrm{year}$ in 1992) entails a 27\% infiltration diminution, from 625 to $456 \mathrm{~mm} /$ year (catchment averages). Considering that most of this infiltrated water is returned to the atmosphere by evapotranspiration, these figures are compatible with those expected in the Sahel region for water consumption by natural savanna and cultivated millet, respectively; unlike the Zimbabwean case cited above, cropping development in this region 
goes with a marked decrease in evaporative demand (e.g.: Bromley et al., 2002; Gash et al., 1997; Payne, 1999, for evapotranspiration from millet fields).

Since increase in indirect groundwater recharge via ponds including or similar to the Wankama pond is considered by hydrogeologists as a main cause for the observed long-term water table rise in the area, it is interesting to compare our estimates for the variation over time of the Wankama pond recharge with those for aquifer recharge. Using isotopic analysis and hydrodynamic modelling of the aquifer on a $4000-\mathrm{km}^{2}$ zone including the Wankama catchment, Favreau et al. (2002a) estimated regional groundwater recharge to have increased by one order of magnitude over the last 50 years, from a $1-5 \mathrm{~mm} / \mathrm{year}$ initial range to $20-50 \mathrm{~mm} / \mathrm{year}$ now. Hydrologic simulations performed in this paper do show an amplification of pond recharge over the period (Figure 5) but by a factor less than 2 .

A simplistic explanation for this discrepancy would be that the Wankama catchment is not characteristic with regard to environmental changes over the whole region on which the hydrogeological interpretation is based. However, this catchment presents one of the highest rates of crop development in the region. The increase in runoff in this catchment should thus be at least as high, if not higher, than in any other in the region. The water table underneath the Wankama pond shows seasonal and interannual variations that are typical of the area, with even larger than average amplitudes.

A more likely explanation could be a change in the infiltration process to the water table that has increased pond efficiency with respect to aquifer recharge. Today, pond water levels are higher than in the past: infiltration now affects the sandy edges of the pond that are less clogged by clay deposits than the center (Desconnets et al., 1997). Also, most of the formerly abundant tree vegetation around the ponds has since been cleared, with a possibly large reduction in evaporative losses. Another probable factor is the following: as a consequence of enhanced surface runoff since 1950, new ponds have appeared in the landscape, resulting in an increased number of sites of preferential infiltration to groundwater. Neglecting runoff to 
ponds created since 1950 would lead to underestimating the groundwater recharge. Along the same idea, infiltration is perhaps not limited to ponds as Desconnets et al. (1996) or Leduc et al. (2001) suggested, but may also occur in spreading zones. Recent surveys confirm that growing spreading zones are a common feature of the landscape. New field measurements need to be carried out to evaluate deep infiltration under these zones.

Other causes of the discrepancy between the estimated change in groundwater recharge and our evaluation of relative runoff change are perhaps to be sought in the parameterisation of the hydrological model. We allocated to the 1950 savanna the same hydraulic conductivity as to the 1992 savanna. Infiltration might be underestimated for the natural environment at that time, when the natural mulch produced by the savanna and under which termites can proliferate was widespread. A recent study (Leonard and Rajot, 2001) shows that infiltration might be increased by a mean factor of 2-3 due to the effect of termites. New simulations should thus be performed with higher $K_{s}$ for the original savanna. Other uncertainties on former catchment states were pointed out in previous sections of this paper, however they should not have any major impact on the conclusions drawn here.

The work presented here is one step in a multi-scale, "multi-angle" study (including in particular, besides catchment runoff hydrology: hydrogeology and geochemistry, investigation of plant/energy and vadose processes, for hillslopes and surface water concentration areas, ...), the objective of which is, by confronting the outputs from these various analyses, to narrow down the estimation ranges for the water balance components and for their variations over the last decades. Hence, a current project aims at modelling runoff through the recent data-rich period (1990-2000) over the same large zone as that considered in the groundwater study, in order to verify at a regional scale whether modelled runoff contributions to ponds and other accumulation areas are consistent with the water table rise observed over the past decade, i.e. with estimates of current aquifer recharge. 


\section{ACKNOWLEDGMENTS}

This work was financed mainly by IRD (Institut de Recherche pour le Développement, France), and in part by the PNRH (French programme for hydrological research).

\section{REFERENCES}

Albergel J. 1987. Sécheresse, désertification et ressources en eau de surface. Application aux petits bassins du Burkina Faso. In The influence of climate change and climatic variability on the hydrologic regime and water resources. Vancouver, 9-22 August 1987, IAHS publ. 168: 355-365.

d'Amato N, Lebel T. 1998. On the characteristics of the rainfall events in the Sahel with a view to the analysis of climate variability. International Journal of Climatology 18: 955-974.

Bajracharya RM, Lal L. 1999. Land use effects on soil crusting and hydraulic response of surface crusts on a tropical Alfisol. Hydrological Processes 13: 59-72.

Bricquet JP, Bamba F, Mahé G, Touré M, Olivry JC. 1997. Évolution récente des ressources en eau de l'Afrique atlantique. Revue des Sciences de l'Eau 3: 321-337.

Bromley J, Taylor C, Gash J. 2002. A comment on « Long-term rise in a Sahelian water-table: the continental terminal in south-west Niger" by Leduc C, Favreau G, Schroeter P. Journal of Hydrology 243: 43-54. Journal of Hydrology 255: 260-262.

Cappelaere B, Peugeot C, Séguis L, Maia A. 2003a. Associer données et modèle incertains: une expérience en petit bassin sahélien. In Hydrology of the Mediterranean and Semiarid Regions, Montpellier, April 2003, IAHS publ. 278: 151-156. 
Cappelaere B, Vieux BE, Peugeot C, Maia A, Séguis L. 2003b. Hydrologic process simulation of a semiarid, endoreic catchment in Sahelian West Niger: 2. Model Calibration and Uncertainty Characterization. Journal of Hydrology, 279(1-4): 244-261.

Casenave A, Valentin C. 1992. A runoff capability classification system based on surface features criteria in semi-arid areas of West Africa. Journal of Hydrology 130: 231-249.

Desconnets JC, Vieux BE, Cappelaere B, Delclaux F. 1996. A GIS for hydrological modelling in the semi-arid, Hapex-Sahel experiment of Niger, Africa. Transaction in GIS 1(2): 82-94.

Desconnets JC, Taupin JD, Lebel T, Leduc C. 1997. Hydrology of the Hapex-Sahel Central Super-Site: surface water drainage and aquifer recharge through the pool systems. Journal of Hydrology 188-189(1-4): 155-178.

Favreau G. 2000. Caractérisation et modélisation d'une nappe phréatique en hausse au Sahel. Thesis, Université Paris XI - Orsay, France; 258.

Favreau G, Leduc C, Marlin C, Dray M, Taupin JD, Massault M, Le Gal La Salle C, Babic M. 2002a. Estimate of recharge of a rising water table in semiarid Niger from ${ }^{3} \mathrm{H}$ and ${ }^{14} \mathrm{C}$ modeling. Ground water 40: 144-151.

Favreau G, Leduc C, Schroeter P. 2002b. Reply to comment on "Long-term rise in a Sahelian water-table: the continental terminal in south-west Niger" by Leduc C, Favreau G, Schroeter P. Journal of Hydrology 243: 43-54. Journal of Hydrology 255: 263-265.

Gash JHC, Kabat P, Monteny BA, Amadou M, Bessemoulin P, Billing H, Blyth EM, deBruin HAR, Elbers JA, Friborg T, Harrison G, Holwill J, Lloyd CR, Lhomme JP, Moncrieff JB, Puech D, Soegaard H, Taupin JD, Tuzet A, Verheof A. 1997. The variability of evaporation 
during the Hapex-Sahel intensive observation period. Journal of Hydrology 188-189(1-4): 385-399.

Gaze, SR, Brouwer J, Simmonds LP, Bromley J. 1998. Dry season water use patterns under Guiera senegalensis L. shrubs in a tropical savanna. Journal of Arid Environments 40: 5367.

Goutorbe JP, Lebel T, Tinga A, Bessemoulin P, Brouwer J, Dolman AJ, Engman ET, Gash JHC, Hoepffner M, Kabat P, Kerr YH, Monteny B, Prince S, Said F, Sellers P, Wallace JS. 1994. Hapex-Sahel: a large-scale study of land atmosphere interactions in the semi-arid tropics. Annalae. Geophysicae 12: 53-64.

d'Herbes JM, Valentin C. 1997. Land surface conditions of the Niamey region: ecological and hydrological implications. Journal of Hydrology 188-189(1-4): 18-42.

Hulme M. 1992. Rainfall changes in Africa : 1931-1960 to 1961-1990. International Journal of Climatology 12: 685-699.

Lamachère JM, Puech C. 1996. Cartographie des états de surface par télédétection et prédétermination des crues des petits bassins versants en zone sahélienne et tropicale sèche. In L'hydrologie tropicale géoscience et outil pour le développement, 2-4 May 1995, IAHS publ. 238: 235-248.

Lebel T, Taupin D, D’Amato N. 1997. Rainfall monitoring during Hapex-Sahel. 1. General rainfall conditions and climatology. Journal of Hydrology 188-189(1-4): 74-96. 
Leduc C, Loireau M, 1997. Fluctuations piézométriques et évolution du couvert végétal en zone sahélienne (sud-ouest du Niger).In Sustainibility of water resources under increasing uncertainty, Rabat 23 April-22 May 1997, IAHS publ. 240: 193-200.

Leduc C, Favreau G, Schroeter P. 2001. Long-term rise in a Sahelian water-table: the continental terminal in south-west Niger. Journal of hydrology 243: 43-54.

Le Houérou HN. 1993. Changements climatiques et désertisation. Sécheresse 4: 95-111.

Léonard JL, Rajot JL. 2001. Influence of termites on runoff and infiltration: quantification and analysis. Geoderma 104: 17-40.

Loireau M. 1998. Espaces, ressources, usages: spatialisation des interactions dynamiques entre les sytèmes sociaux et les systèmes écologiques au Sahel nigérien. Thesis, Université Montpellier III, France; 400.

Lørup JK, Refsgaard JC, Mazvimavi D. 1998. Assessing the effect of land use change on catchment runoff by combined use of statistical tests and hydrological modelling: Case studies from Zimbabwe. Journal of hydrology 205: 147-163.

Lubès-Niel H, Séguis L, Sabatier R. 2001. Étude de stationnarité des caractéristiques des évènements pluvieux de la station de Niamey sur la période 1956-1998. Comptes Rendus de l'Académie des Sciences - series Ila, 333: 645-650.

Mahé G, Olivry JC, Dessouassi R, Orange D, Bamba F, Servat E. 2000. Relations eaux de surface-eaux souterraines d'une rivière tropicale au Mali. Comptes Rendus de l'Académie des Sciences - series IIa, 330: 889-892. 
Mahé G, Leduc C, Amani A, Paturel JE, Girard S, Servat E, Dezetter A. 2003. In Hydrology of Mediterranean and Semiarid Regions, Montpellier,April 2003 IAHS publ. 278: 215-222.

Nicholson SE, Some B, Kone B. 2000. An analysis of recent rainfall conditions in West Africa, including the rainy seasons of the $1997 \mathrm{El}$ Nino and the 1998 La Nina years. Journal of Climate 13: 2628-2640.

Paturel JE, Servat E, Kouamé E, Lubès H, Fritsch JM, Masson JM. 1997. Manifestations d'une variabilité hydrologique en Afrique de l'Ouest et Centrale. In Sustainability of water resources under increasing uncertainity, Rabat 23 April-22 May 1997, IAHS publ. 240: 2130.

Payne WA. 1999. Shallow tillage with a traditional West African hand hoe to conserve soil water. Soil Science Society of America Journal, 63: 972-976.

Peugeot C, Estèves M, Galle S, Rajot JL, Vandervaere JP. 1997. Runoff generation, processes: results and analysis of field data collected at the East Central Supersite of the Hapex-Sahel experiment. Journal of Hydrology 188-189(1-4): 179-202.

Peugeot C, Cappelaere B, Vieux BE, Séguis L, Maia A. 2003. Hydrologic process simulation of a semiarid, endoreic catchment in Sahelian West Niger: 1. Model-aided data analysis and screening. Journal of Hydrology, 279(1-4): 224-243.

Pouyaud B. 1987. Variabilité spatiale et temporelle des bilans hydriques de quelques bassins versants d'Afrique de l'ouest en liaison avec les changements climatiques. In The influence of climate change and climatic variability on the hydrologic regime and water ressources. Vancouver, 9-22 August 1987, IAHS publ. 168: 447-461. 
Séguis L, Cappelaere B, Peugeot C, Vieux B. 2002. Impact on Sahelian runoff of stochastic and elevation induced spatial distributions of soil parameters. Hydrological processes 16:313322.

Servat E, Paturel JE, Lubès-Niel H, Kouamé B, Travaglio M, Marieu B. 1997. De la diminution des écoulements en Afrique de l'Ouest et centrale. Comptes Rendus de l'Académie des Sciences - series Ila, 325:679-682.

USACE. 1993. GRASS 4.1 User's Reference Manual. Construction Engineering Research Laboratories US Army Corps of Engineers: Champaign, Illinois.

Valentin C. 1986. Différencier les milieux selon leur aptitude au ruissellement: une cartographie adaptée aux besoins hydrologiques. In Premières Journées hydrologiques de l'Orstom à Montpellier, 17-18 September 1985, Orstom publ., Paris: 50-74.

Valentin C. 1991. Surface crusting in two alluvial soils of northern Niger. Geoderma 48: 201-222.

Valentin C. 1994. Sécheresse et érosion au Sahel. Sécheresse 5: 191-198.

Vandervaere JP, Peugeot C, Vauclin M, Angulo Jaramillo R, Lebel T. 1997. Estimating hydraulic conductivity of crusted soils using disc infiltrometers and minitensiometers. Journal of Hydrology 188-189(1-4): 203-223.

Vieux BE, Gaur N. 1994. Finite-element modeling of storm water runoff using GRASS GIS. Microcomputers in civil engineering 9: 263-270. 
Table 1. Occupation rates and hydraulic characteristics of surface features of the Wankama catchment $\left(K_{s}\right.$ : saturated hydraulic conductivity; $n$ : Manning's coefficient)

\begin{tabular}{|c|c|c|c|c|c|}
\hline \multirow[t]{2}{*}{ Class } & \multicolumn{3}{|c|}{ Surface area (\%) } & \multirow{2}{*}{$\begin{array}{c}K_{s} \\
\left(\times 10^{-7} \mathrm{~m} \mathrm{~s}^{-1}\right)\end{array}$} & \multirow{2}{*}{$\begin{array}{c}n \\
\left(\times 10^{-3} \mathrm{~m}^{-1 / 3} \mathrm{~s}\right)\end{array}$} \\
\hline & 1950 & 1975 & 1992 & & \\
\hline Field & 6.0 & 13.4 & 53.9 & 36 & 130 \\
\hline Fallow & 0.0 & 3.2 & 1.9 & 56 & 149 \\
\hline Sparse shrub savanna & 57.4 & 55.9 & 23.9 & 56 & 174 \\
\hline Dense shrub savanna & 19.1 & 0.0 & 0.0 & 56 & 200 \\
\hline Dense vegetation thicket & 8.6 & 4.3 & 0.2 & 111 & 277 \\
\hline Degraded hillslope & 3.1 & 9.4 & 6.4 & 8 & 46 \\
\hline Highly degraded hillslope & 3.6 & 11.9 & 10.5 & 11 & 15 \\
\hline Sparse vegetation: plateau & 1.4 & 0.0 & 0.5 & 111 & 277 \\
\hline Bare soil: plateau & 0.8 & 1.9 & 2.6 & 6 & 20 \\
\hline
\end{tabular}

Table 2. Ratios of mean annual runoff for each land cover map $\left(\mathrm{V}_{1950}, \mathrm{~V}_{1975}\right.$ and $\left.\mathrm{V}_{1992}\right)$, with two spreading zone widths ( 2 and $225 \mathrm{~m}$ )

\begin{tabular}{cccc}
\hline Spreading zone width & $\mathrm{V}_{1992} / \mathrm{V}_{1950}$ & $\mathrm{~V}_{1992} / \mathrm{V}_{1975}$ & $\mathrm{~V}_{1975} / \mathrm{V}_{1950}$ \\
\hline $2 \mathrm{~m}$ & 2.6 & 1.5 & 1.7 \\
$225 \mathrm{~m}$ & 2.8 & 1.5 & 1.8 \\
\hline
\end{tabular}

Table 3. Mean annual runoff for each land cover $\left(\mathrm{V}_{1950}, \mathrm{~V}_{1975}\right.$ and $\left.\mathrm{V}_{1992}\right)$ and relative deficit from wet (1950-1969) to dry (1970-1998) climatic period

\begin{tabular}{|c|c|c|c|c|c|c|c|}
\hline & \multirow[b]{2}{*}{$\begin{array}{c}\text { Rainfall } \\
(\mathrm{mm})\end{array}$} & \multicolumn{3}{|c|}{ Spreading zone $2 \mathrm{~m}$} & \multicolumn{3}{|c|}{ Spreading zone $225 \mathrm{~m}$} \\
\hline & & $\begin{array}{l}\mathrm{V}_{1950} \\
(\mathrm{~mm})\end{array}$ & $\begin{array}{l}\mathrm{V}_{1975} \\
(\mathrm{~mm})\end{array}$ & $\begin{array}{l}\mathrm{V}_{1992} \\
(\mathrm{~mm})\end{array}$ & $\begin{array}{l}V_{1950} \\
(\mathrm{~mm})\end{array}$ & $\begin{array}{l}\mathrm{V}_{1975} \\
(\mathrm{~mm})\end{array}$ & $\begin{array}{l}\mathrm{V}_{1992} \\
(\mathrm{~mm})\end{array}$ \\
\hline 1950-1969 period & 645.8 & 27.7 & 47.2 & 71.6 & 21.1 & 38.8 & 58.1 \\
\hline 1970-1998 period & 497.7 & 17.2 & 28.6 & 44.7 & 13.0 & 23.3 & 36.3 \\
\hline $\begin{array}{l}\text { Relative wet to dry } \\
\text { period deficit }\end{array}$ & 0.23 & 0.38 & 0.40 & 0.37 & 0.38 & 0.39 & 0.38 \\
\hline
\end{tabular}


Figure 1. Surface feature maps of the Wankama catchment during the last 50 years

Figure 2. Annual rainfall at Niamey Airport during the past 50 years and mean annual rainfall for the wet (1950-1969) and dry (1970-1998) periods

Figure 3. Simulated annual runoff versus annual rainfall (49 years) for the three land cover maps (1950, 1975 and 1992) and for the two widths of the spreading zone (2 and $225 \mathrm{~m}$ ); each vertical bar represents the interval between extreme runoff values from $23(\mathrm{~K}, \mathrm{C}, \mathrm{M})$ parameter sets, around the symbol-marked value for the optimal calibrated set

Figure 4. Relative contributions of rainfall depth classes to the total rainfall and runoff deficits (wet period minus dry period); runoff deficits are calculated for the 1992 land use and the $225 \mathrm{~m}$ spreading zone

Figure 5. Ratios of changes in simulated mean annual runoff (bold numbers) for realistic environmental and climatic scenarios including spreading zone hypotheses, over the last fifty years 
Figure 1

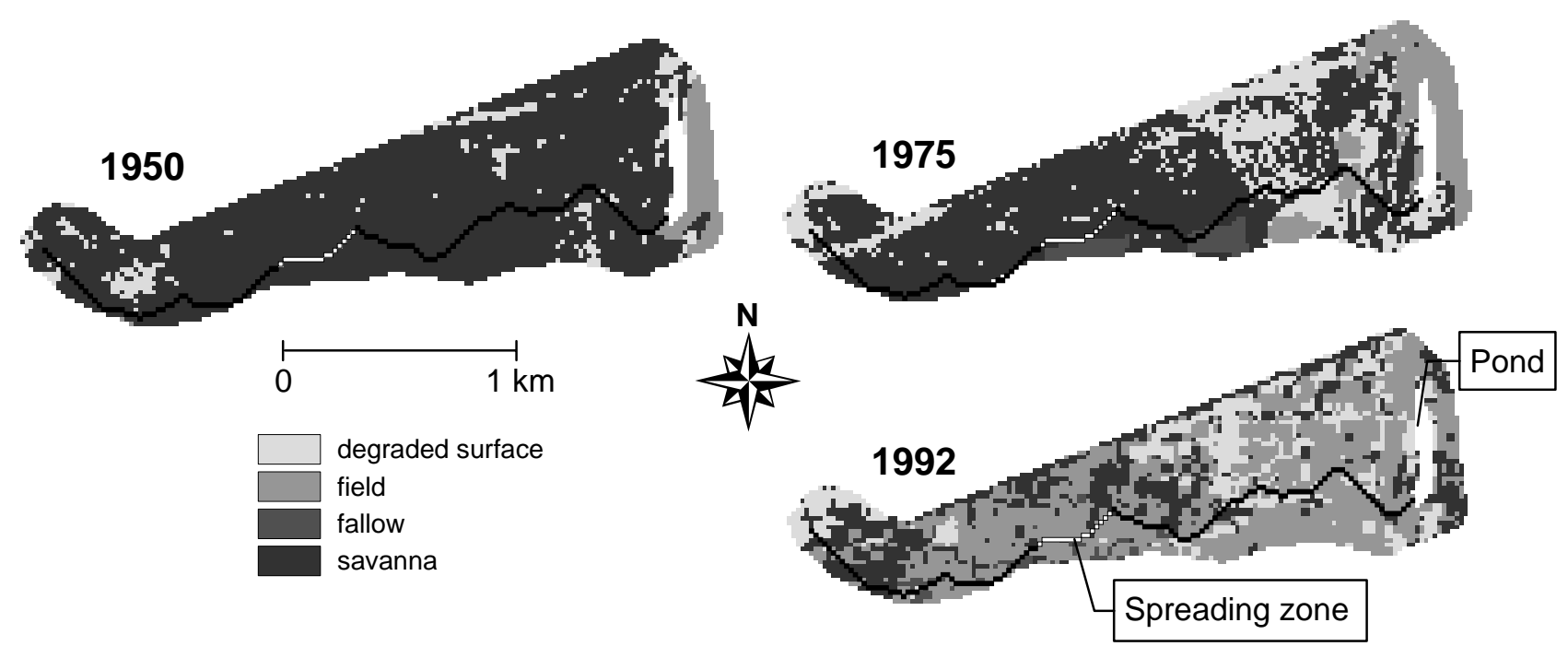


Figure 2

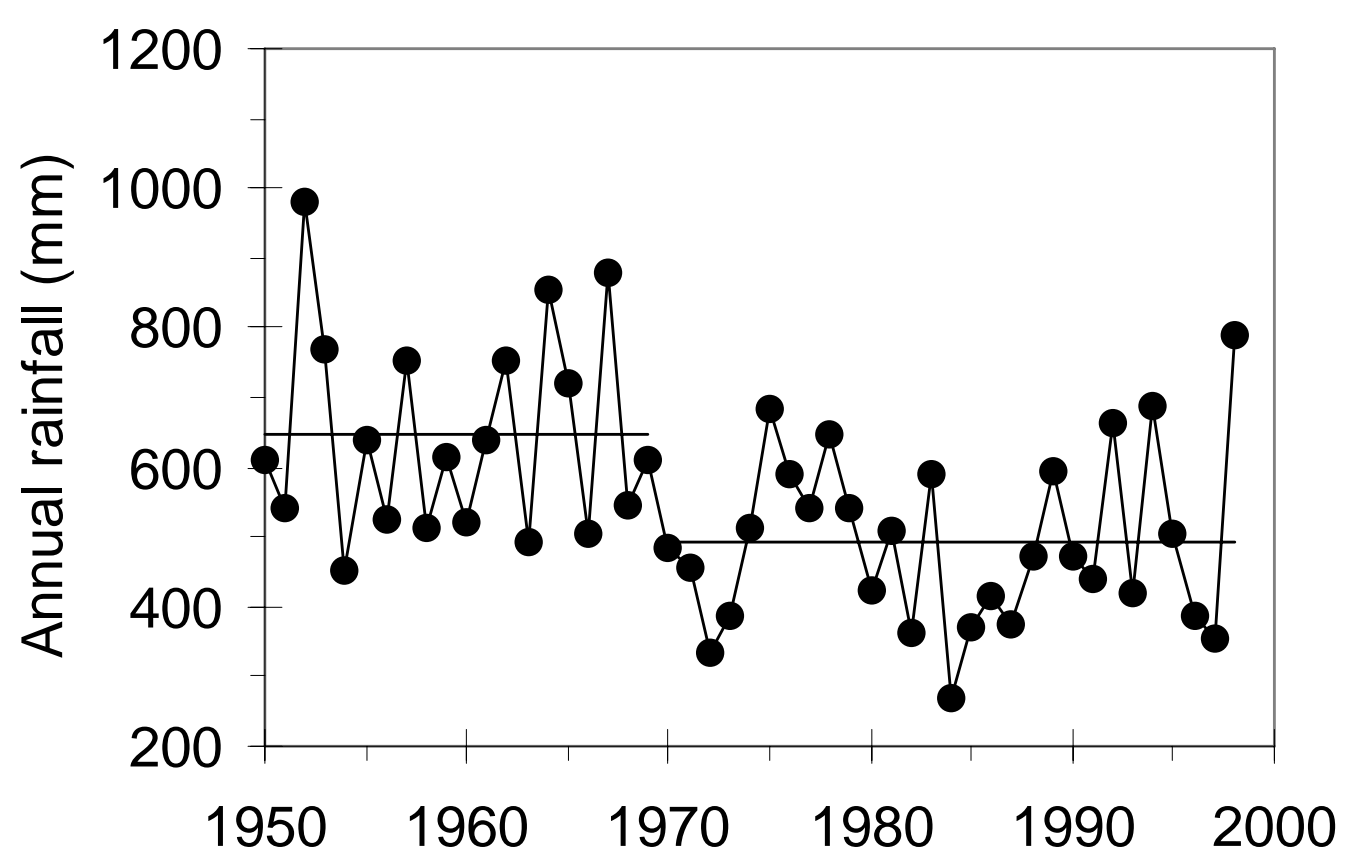


Figure 3
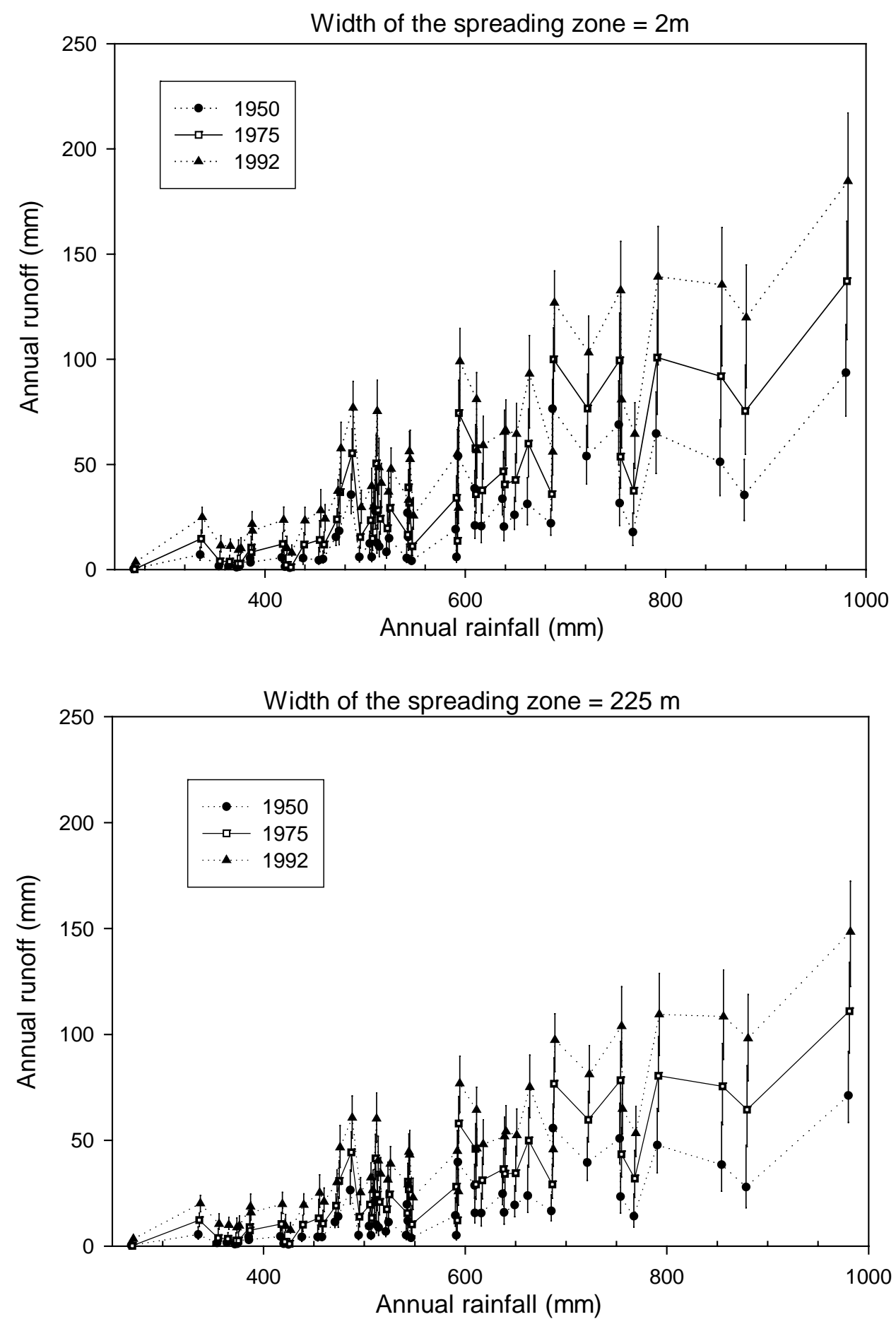
Figure 4

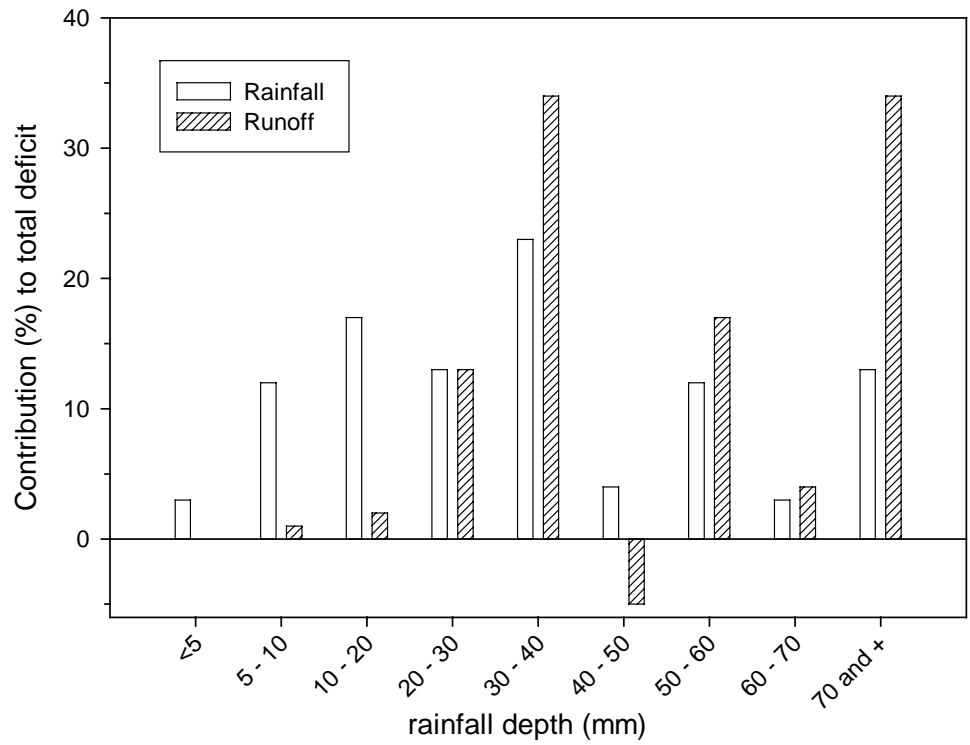




\section{Figure 5}

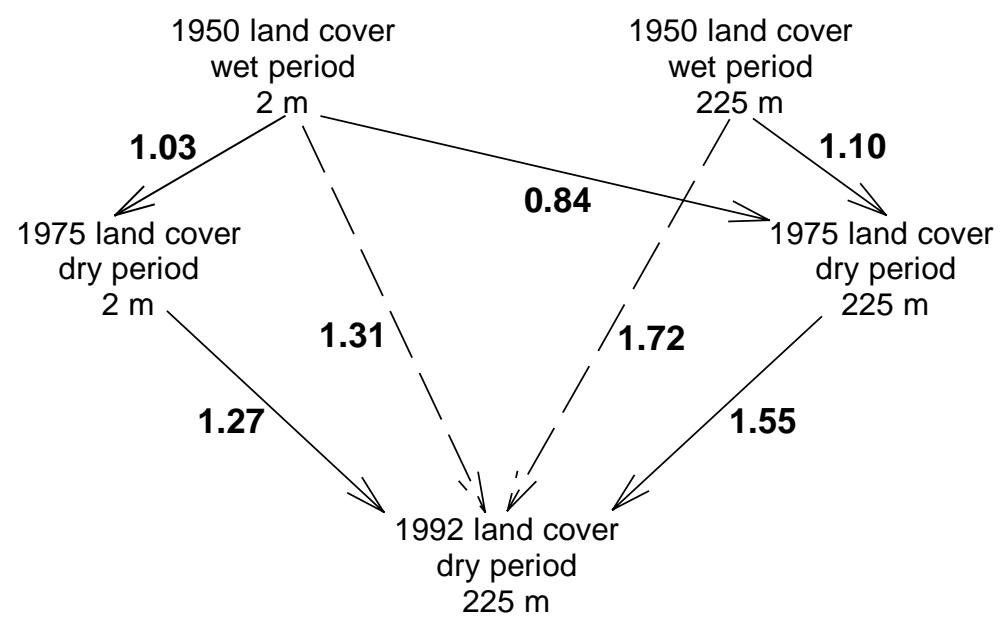

